\title{
Estimation of Demineralisation Activity of Soft Drinks on Extracted Teeth - in vitro Study
}

\author{
Ramya $\mathrm{G}^{1}$ and N.P. Muralidharan ${ }^{2}$ \\ ${ }^{1}$ Saveetha Dental College and Hospitals, Saveetha institute of medical and \\ technical sciences (SIMATS), Saveetha University, Chennai - 600077, India. \\ ${ }^{2}$ Associate Professor, Department of Microbiology, Saveetha Dental College and Hospitals, Saveetha \\ institute of medical and technical sciences (SIMATS), Saveetha University, Chennai - 600077, India.
}

\section{ABSTRACT}

We consume a variety of soft drinks in our day to day life, the pH of these soft drinks and chemicals used in these soft drinks as preservatives can have an impact on the teeth, saliva and the other components of oral mucosa.To analyse the demineralisation effect of soft drinks on extracted teeth. Extracted teeth were rinsed and sterilised. The teeth were then subjected to the hot air oven, their weight measured in an electrical balance and ten teeth were put in each soft drink of the same quantity. Water was used as a control and ten teeth were added in the test tube containing water. Then their weight was analysed again after stipulated hours and the difference in weights noted and results interpreted.The analysis showed that there was a reduction in the weight of the teeth which was subjected to soft drinks. This could be due to the eroding effect of the chemicals i.e.,. acids and sugars present in the soft drinks which reduced the mineral content of the teeth, especially the calcium and hydroxyapatite. In this study it was found that both carbonated and non carbonated drinks have an eroding effect on the tooth structure which can be seen as a difference in their dry weights, before and after exposure.

\section{KEY WORDS: DEMINERALISATION ;EROSION; EXTRACTED TEETH ; PH ; SOFT DRINKS; SUGARS..}

\section{INTRODUCTION}

Dental erosion is defined as an irreversible loss of the dental structure on exposure to chemicals and without the involvement of microorganisms. This process is a result of the action of acids whose $\mathrm{pH}$ is lower than 4.5 (Al-Majed, Maguire and Murray, 2002). Enamel is the hardest substance in the body, and it protects the coronal pulp of the teeth. However, it is susceptible to

\section{ARTICLE INFORMATION}

*Corresponding Author: muralidharan@saveetha.com

Received 15th June 2020 Accepted after revision 10th August 2020

Print ISSN: 0974-6455 Online ISSN: 2321-4007 CODEN: BBRCBA

Thomson Reuters ISI Web of Science Clarivate Analytics USA and Crossref Indexed Journal

\section{Clarivate
Analytics}

NAAS Journal Score 2020 (4.31) SJIF: 2020 (7.728)

A Society of Science and Nature Publication,

Bhopal India 2020. All rights reserved.

Online Contents Available at: http//www.bbrc.in/

Doi: http://dx.doi.org/10.21786/bbrc/13.7/78 demineralisation by acids. Acids are produced when certain bacteria colonise the tooth surface and metabolise carbohydrates. If the above condition accelerates, it eventually leads to the development of carious lesions in the enamel and dentin. Another source of acid is dietary intake of the individuals. Many foods and beverages contain acids that also would lead to demineralisation of the enamel (Attin et al., 2003).

Soft drinks contain several acids and sugars which are potentially both acidogenic and cariogenic (Attin et al., 2005; Bozec et al., 2005). These acids which are produced by soft drinks along with gastric acid can elicit heavy fumes travelling from the stomach through the oesophagus to the mouth which can mineralised tooth structures. These beverages create a devastating impact on a patient's health by causing degradation of the mineralised tooth structures, increasing tooth sensitivity and inducing changes in appearance of teeth and their

\section{8}


colour. The pattern of erosion changes depending upon the frequency of dental tissue which is being exposed to acidic fumes (Larsen and Nyvad, 1999).

Infective damage or tooth caries occurs as a consequence of demineralisation caused by the bacteria organised in a special ecological formation: oral biofilm - dental plaque. In certain conditions, the so-called cariogenic bacteria (specific species of streptococci) dominate on the tooth surface (Barbour et al., 2005, 2006). They can create organic acids but simultaneously can survive in acidic conditions. They suppress neutral or useful bacteria. For acidogenic biofilms to form and exert a cariogenic effect, the presence of sugar is necessary (Sayegh et al., 2002). Degradation of enamel is a complex phenomenon, but erosion appears to be the predominating factor at low pH levels (Johansson et al., 1996; Wang et al., 2010). This study aims to analyse the demineralisation effect of soft drinks on enamel in an in vitro condition by comparing the weight of hard tissue before and after exposure to a known concentration of soft drinks.

\section{MATERIAL AND METHODS}

Extracted teeth were sealed in the apical region, rinsed with water and placed in a hot air oven at 50 degree celsius for 30 mins. They were weighed and exposed to known concentrations of soft drinks for $15 \mathrm{mins}, 1$ hour, 90mins subsequently.

The soft drinks selected were as follows :

Soft drinks:

- Carbonated products

- Non carbonated products
Carbonated:
1. C1
2. $\mathrm{C} 2$
3. $\mathrm{C} 3$

Non carbonated:

1. N1

2. $\mathrm{N} 2$

3. N3

Water used as control.

This study was performed with 10 dried extracted teeth samples in each group. The teeth samples were weighed and were subjected to exposure to $\mathrm{C} 1, \mathrm{C} 2, \mathrm{C} 3, \mathrm{~N} 1, \mathrm{~N} 2, \mathrm{~N} 3$ and water in separate test tubes. Then the weights of the teeth present in each test tube was assessed subsequently after exposure for 15mins, then placed back in the test tube and again weighed after 60mins, then placed back into their respective test tubes and then finally assessed for the difference in weight if any at the end of 90mins. The differences in weights were noted down and the data was tabulated and represented graphically.

\section{RESULTS AND DISCUSSION}

Of the carbonated drinks, C2 showed the greatest demineralisation effect as the teeth subjected to C2 showed significant loss of weight after subject to exposure for 1.5 hours. Of the non carbonated drinks, N3 shows the maximum demineralising effect ( table 1 )

Erosion is a non carious tooth surface lesion, in which there is continuous loss of enamel and dentin that is

\begin{tabular}{|c|c|c|c|c|c|c|c|}
\hline $\begin{array}{l}\text { SOFT } \\
\text { DRINKS }\end{array}$ & $\begin{array}{c}C 1 \\
(n=10)\end{array}$ & $\begin{array}{c}C 2 \\
(n=10)\end{array}$ & $\begin{array}{c}\text { C3 } \\
(n=10)\end{array}$ & $\begin{array}{c}\mathrm{N} 1 \\
(\mathrm{n}=10)\end{array}$ & $\begin{array}{c}\mathrm{N} 2 \\
(\mathrm{n}=10)\end{array}$ & $\begin{array}{c}\text { N3 } \\
(n=10)\end{array}$ & $\begin{array}{l}\text { WATER } \\
(n=10)\end{array}$ \\
\hline $\begin{array}{l}\text { BEFORE } \\
\text { EXPOSURE }\end{array}$ & $5.02 \mathrm{~g}$ & $6.45 \mathrm{~g}$ & $5.31 \mathrm{~g}$ & $5.21 \mathrm{~g}$ & $4.32 \mathrm{~g}$ & $4.75 \mathrm{~g}$ & $11.57 \mathrm{~g}$ \\
\hline $\begin{array}{l}\text { (MEAN) } \\
\text { After 15mins } \\
\text { (MEAN) }\end{array}$ & $5.02 \mathrm{~g}$ & $6.45 \mathrm{~g}$ & $5.31 \mathrm{~g}$ & $5.21 \mathrm{~g}$ & $4.32 \mathrm{~g}$ & $4.75 \mathrm{~g}$ & $11.57 \mathrm{~g}$ \\
\hline $\begin{array}{l}\text { After 60mins } \\
\text { (MEAN) }\end{array}$ & $4.98 \mathrm{~g}$ & $5.95 \mathrm{~g}$ & $5.28 \mathrm{~g}$ & $5.16 \mathrm{~g}$ & $4.29 \mathrm{~g}$ & $4.68 \mathrm{~g}$ & $11.57 \mathrm{~g}$ \\
\hline $\begin{array}{l}\text { After 90mins } \\
\text { (MEAN) }\end{array}$ & $4.87 \mathrm{~g}$ & $5.63 \mathrm{~g}$ & $5.21 \mathrm{~g}$ & $5.11 \mathrm{~g}$ & $4.23 \mathrm{~g}$ & $4.63 \mathrm{~g}$ & $11.57 \mathrm{~g}$ \\
\hline
\end{tabular}

chemically etched away from the tooth surface by acid/ or chelation without bacterial involvement (Jarvinen, Rytomaa and Heinonen, 1991)

From the study it was observed that out of the various carbonated drinks in which teeth were immersed, C2 showed the maximum loss of weight followed by $\mathrm{C} 1$ and then C3. Among the non carbonated drinks teeth immersed in N2 shows the maximum change in weight followed by N1 and N3. Water was considered as a control in this study due to its neutral $\mathrm{pH}$.

The erosion of calcium content of enamel present in the hydroxyapatite structure is due to the acids and sugars present in these soft drinks. The difference between the results in carbonated drinks versus non carbonated drinks reveals that carbonated drinks have carbon gas and increase sugar content for the 'fizz' feeling while non 
carbonated drinks also possess acids and sugars which have a potential to slowly erode the enamel surface.

The eroding activity can differ from one individual to another. This is due to the frequency of consumption of soft drinks by the individual, the amount of time the drink is retained in an individual's oral cavity, their general lifestyle and dietary habits, personal habits, systemic conditions.

Figure 1: Bar chart depicting the difference in weights of the teeth on exposure to various soft drinks at various time intervals as observed in this study

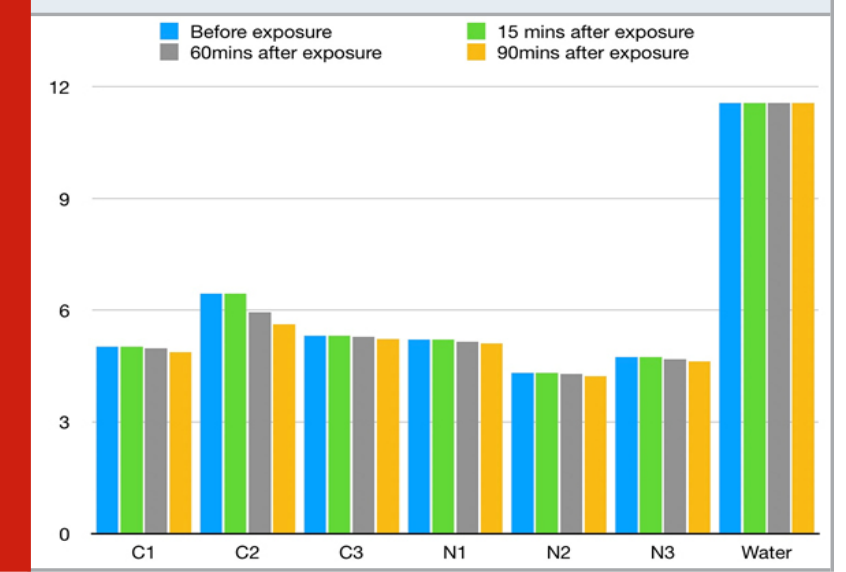

The decrease in weight with increase in time indicates that the increase in exposure to beverages and fruits which contains high levels of citric, phosphoric acids, dietary sugars can pave the way to formation of the biofilm and subsequently the dental plaque. This leads to accumulation of the oral microorganisms which can cause dental caries in them.

The inherent acids and sugars have both acidogenic and cariogenic potential, resulting in dental caries and potential enamel erosion. Continuously sipping soda creates an acid bath for teeth (Luo et al., 2005). This softened several areas of the teeth which is ideal for bacteria to enter and facilitate dental caries formation. As well, the sugar content of the soda is converted to acid by the cariogenic bacterias. Among children, dental erosions are mainly caused by excessive consumption of erosive soft drinks. Growing evidence suggests that there is considerable increase in consumption of potentially erosive drinks among children in the last decade.(Lussi and Jaeggi, 2008). Reports have also been published regarding significant associations between soft drink consumption and dental erosion (Tahmassebi et al., 2006).

Soft drinks with high calcium contents have significantly lower erosive potential while Low $\mathrm{pH}$ value and high citric acid content may cause more surface loss. As the erosive time elongates, the titratable acidity to $\mathrm{pH} 7$ may be a predictor of erosive potential for acidic soft drinks. The erosive potential of the soft drinks may be predicted based on the types of acid content, $\mathrm{pH}$ value, titratable acidity, and ion concentration (Aas et al., 2005, 2008)

Literature reveals that there exists a positive relationship between caries, dental erosion and the consumption of soft drinks (Badra et al., 2005; Hemingway et al., 2006; Barbour and Shellis, 2007; Lutovac et al., 2017). Accordingly, the clinical manifestations and diagnosis of diseases caused by soft drinks should be regarded as a combination of erosion and caries, and clinicians should pay more attention to it.

\section{CONCLUSION}

In this study it was found that both carbonated and non carbonated drinks have an eroding effect on the tooth structure which can be seen as a difference in their weights, before and after exposure. Hence consumption of soft drinks will have eroding activities.

\section{REFERENCES}

Aas, J. A. et al. (2005) 'Defining the normal bacterial flora of the oral cavity', Journal of clinical microbiology, 43(11), pp. 5721-5732.

Aas, J. A. et al. (2008) 'Bacteria of Dental Caries in Primary and Permanent Teeth in Children and Young Adults', Journal of Clinical Microbiology, pp. 14071417. doi: 10.1128/jcm.01410-07.

Al-Majed, I., Maguire, A. and Murray, J. J. (2002) 'Risk factors for dental erosion in 5-6 year old and 12-14 year old boys in Saudi Arabia', Community Dentistry and Oral Epidemiology, pp. 38-46. doi: 10.1034/j.16000528.2002.300106.x.

Attin, T. et al. (2003) 'Effect of mineral supplements to citric acid on enamel erosion', Archives of oral biology, 48(11), pp. 753-759.

Attin, T. et al. (2005) 'Impact of modified acidic soft drinks on enamel erosion', Oral Diseases, pp. 7-12. doi: 10.1111/j.1601-0825.2004.01056.x.

Badra, V. V. et al. (2005) 'Influence of different beverages on the microhardness and surface roughness of resin composites', Operative dentistry, 30(2), pp. 213-219.

Barbour, M. E. et al. (2005) 'Human enamel erosion in constant composition citric acid solutions as a function of degree of saturation with respect to hydroxyapatite', Journal of oral rehabilitation, 32(1), pp. 16-21.

Barbour, M. E. et al. (2006) 'The relationship between enamel softening and erosion caused by soft drinks at a range of temperatures', Journal of dentistry, 34(3), pp. 207-213.

Barbour, M. E. and Shellis, R. P. (2007) 'An investigation using atomic force microscopy nanoindentation of dental enamel demineralization as a function of undissociated acid concentration and differential buffer capacity', Physics in medicine and biology, 52(4), pp. 899-910.

Bozec, L. et al. (2005) 'Mineralised tissues as nanomaterials: analysis by atomic force microscopy’, 
IEE proceedings. Nanobiotechnology, 152(5), pp. 183-186.

Hemingway, C. A. et al. (2006) 'Erosion of enamel by non-carbonated soft drinks with and without toothbrushing abrasion', British Dental Journal, pp. 447-450. doi: 10.1038/sj.bdj.4814073.

Jarvinen, V. K., Rytomaa, I. I. and Heinonen, O. P. (1991) 'Risk Factors in Dental Erosion', Journal of Dental Research, pp. 942-947. doi: 10.1177/00220345910700060601.

Johansson, A.-K. et al. (1996) 'Dental erosion, soft-drink intake, and oral health in young Saudi men, and the development of a system for assessing erosive anterior tooth wear', Acta Odontologica Scandinavica, pp. 369-378. doi: 10.3109/00016359609003554.

Larsen, M. J. and Nyvad, B. (1999) 'Enamel Erosion by Some Soft Drinks and Orange Juices Relative to Their $\mathrm{pH}$, Buffering Effect and Contents of Calcium Phosphate', Caries Research, pp. 81-87. doi: 10.1159/000016499.

Luo, Y. et al. (2005) 'The prevalence of dental erosion in preschool children in China', Journal of dentistry, 33(2), pp. 115-121.

Lussi, A. and Jaeggi, T. (2008) 'Erosion--diagnosis and risk factors', Clinical oral investigations, 12 Suppl 1, pp. S5-13.

Lutovac, M. et al. (2017) 'Testing the Effect of Aggressive Beverage on the Damage of Enamel Structure', Open access Macedonian journal of medical sciences, 5(7), pp. 987-993.

Sayegh, A. et al. (2002) 'Food and drink consumption, sociodemographic factors and dental caries in 4-5-yearold children in Amman, Jordan', British Dental Journal, pp. 37-42. doi: 10.1038/sj.bdj.4801478.

Tahmassebi, J. F. et al. (2006) 'Soft drinks and dental health: a review of the current literature', Journal of dentistry, 34(1), pp. 2-11.

Wang, P. et al. (2010) 'The prevalence of dental erosion and associated risk factors in 12-13-year-old school children in Southern China', BMC Public Health. doi: 10.1186/1471-2458-10-478. 